\title{
Custard Apple Seed Extract as a Preventive Measure to Control Downy Mildew of Grapes
}

\author{
Sonali S Mali, Ravina R Khilare, Shweta S Gurav, Suryakant S Wadkar, Chidanand C Shete and Jai S Ghosh* \\ Department of Biotechnology, Smt KW College, India
}

Submission: July 07, 2018, Published: July 19, 2018

"Corresponding author: Jai S Ghosh, Department of Biotechnology, Smt. KW College, India, Tel: +919850515620; Email: ghoshjai@gmail.com

\begin{abstract}
The mildew diseases of grapes takes a heavy toll on the yield especially in tropical and rain fed regions of the world. There are several chemical fungicides available to manage the diseases. However, the residual effects of these fungicides are equally damaging as the diseases themselves and the cultivators bears the cost of these damages. This investigation is aimed to study some effective biocontrol agents as preventive measure rather than cure for the mildew disease. It has been observed that the aqueous extract of the seeds of Annona squamosa and Annona reticulate can bring about such prevention of these diseases.
\end{abstract}

Keywords: Grapes; Mildew; Biofungicides; Annona squamosa: Plasmopara viticola

\section{Introduction}

Grape vine (Vitis vinifera) belongs to the family Vitaceae of the order Rhamnales [1]. It is a vine and is susceptible to many fungal diseases along with pest infestations. Of the two major fungal diseases that take a heavy toll on the economics of the cultivators are the powdery mildew and downy mildew [2]. The causative agent of powdery mildew disease is the fungus Uncinula necator, renamed as Erysiphe necator (Schw.) Burr [3]. This fungi belongs to the Ascomycota group of fungi, in the family Erysiphaceae. Downey mildew is caused by the fungi Plasmopara viticola a fungi that belongs to Oomycetes group of fungi in the Peronosporaceae family [4]. Both the fungi are obligate biotrophs and cannot be grown in vitro [5]. All green tissues of the plants including the skin of the berries are susceptible to these diseases. The disease manifestation occurs when there is high humidity, preferably a wet spell for 24 hours but the temperature should not be very high (around $55^{\circ} \mathrm{F}$ i.e. $13^{\circ} \mathrm{C}$ to $85^{\circ} \mathrm{F}$ i.e. $30^{\circ} \mathrm{C}$ with an optimum temperature of $20^{\circ} \mathrm{C}$ ) [6].

The disease downy mildew, usually seen on the lower surface of the leaf, as these are directly in the high moisture region, being close to the soil. The disease is controlled by spraying with Bordeaux mixture and today other fungicides are also used like wettable sulfur etc. [7]. However, all these fungicides have a serious residual effect and many a times cannot be easily removed by washing with water. This disease is best managed by adopting preventive measure rather than trying to control it after it appears. This is because by the time visible symptoms are seen, the extensive damage has already been done including fall of premature berries [4], The disease spreads very rapidly as the spores are air borne and is scattered by splash of rain drops on the soil.

This investigation was aimed to search for a phytochemical which will be preferably harmless or less toxic to humans but can be applied as a preventive measure (foliar spray) as soon as the predisposing factors which include climatic changes are seen favoring the onset of the disease.

It was observed from the past reports that the extracts of seeds of custard apple (Annona squamosa and Annona reticulata) belonging to the order Magnoliales and family Annonaceae [8], have good antifungal properties (as seen from on application as traditional medicine for control of the dermitidis caused by a lipohilic yeast Malassezia spp) [9]. It was therefore, decided to try the different extracts of these seeds as a prospective biological control agent for downy mildew infection.

\section{Materials and Methods}

\section{The seeds of custard apple}

The seeds of the fruit were obtained from certain food processors who process the pulp of custard apples for making milk shakes.

\section{Extracts of the seeds}

The seeds were sundried and then crushed coarsely in a blender. The pulverized material was extracted with different solvents like water, ethanol, acetone and methanol. Two different methods of extraction were used: 
a. It was soaked separately in respective solvents at $10 \%$ level (w/v) and then shaken on a rotary shaker at $120 \mathrm{rpm}$ for 2 hrs.

b. The other method of extraction was by the soxhlet method [10] at $80^{\circ} \mathrm{C}$ for 2 hrs.

In both cases the extracts were dried using a water bath adjusted at $80^{\circ} \mathrm{C}$ to note the total solid content. These were then redissolved in the respective solvent with known concentrations.

\section{Antifungal properties of the extracts}

These experiments were carried out to confirm that the extracts had antifungal properties. The experiments were carried out in vitro using standard cultures of Penicillium notatum and Aspergillus niger. This is because the causative agent of downy mildew - Plasmopara viticola, is an obligate parasite and cannot be grown on artificial medium. The organisms were grown on solid Saboroud's medium (dextrose 20\%; peptone 10\%; pH adjusted to 5.5 to 5.6) to sporulation. A saline suspension of the spores, containing 108 spores $/ \mathrm{mL}$, was inoculated on the same liquid medium along with the extract at $1300 \mu \mathrm{g} / \mathrm{mL}$ and the solvents were at $5 \%$ in the media $(\mathrm{v} / \mathrm{v})$. The activities were tested using the protein content of the biomass as the indicator of growth. The flasks were incubated at $28^{\circ} \mathrm{C}$ on a rotary shaker at $150 \mathrm{rpm}$ for $48 \mathrm{hrs}$. The biomass was filtered, centrifuged at $2800 \mathrm{xg}$ and the nitrogen content was estimated by micro Kjeldhal method [11]. The nitrogen content was then converted to protein content [12].

All attempts to get callus of grape in the laboratory to grow the fungi $P$. viticola were not successful and hence the most effective extracts showing maximum antifungal property at the above mentioned concentration was directly tested on leaves in grape vines.

\section{Results and Discussion}

It was observed that all the extracts inhibited the growth of the two fungi viz. Penicillium notatum and Aspergillus niger at the concentration of the extract as mentioned before. With this in vitro data it was decided to apply the extracts on a section of the vine yard just before the onset of light rains (resulting in high humidity and rise in temperature due to cloudy conditions) in the peak season i.e. during the month of late December. The results are as shown in Figure 1.
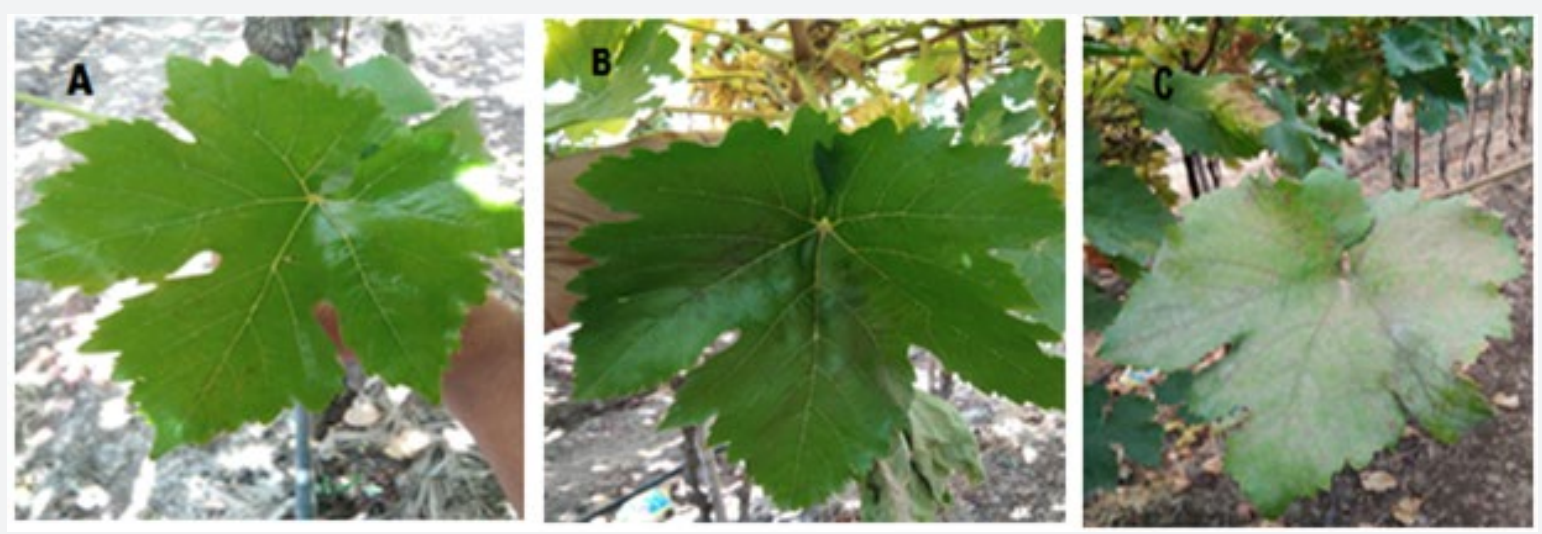

Figure 1: The effect of application of different extracts of custard apple seed. [A] Application of ethanol, or acetone or methanol extracts results in damage to the chlorophyll in the leaf making it look pale green. [B] Application of aqueous extract which does not damage the chlorophyll of the leaf. [C] The untreated leaf showing it was heavily infected with both powdery and downy mildew.

It could be seen that the leaves which had received the extract showed no symptoms of the disease - downy mildew as compared to the leaves which did not receive the extracts. Further, it was also observed that the seed extract of custard apple also inhibited powdery mildew caused by Erysiphe necator. The solvent extracts like ethanol, acetone and methanol were avoided as these solvents could damage the chlorophyll (since these could dissolve the chlorophyll and leach it out of the leaves) in the healthy leaves resulting in physiological stress on photosynthesis. Only aqueous extract was used which would cause minimum or no physiological stress to the leaves.

\section{Conclusion}

It was therefore, concluded that a preventive treatment of aqueous extract of the seeds of custard apple could reduce the heavy damage caused by the disease of downy mildew. It proved to be a good biocontrol agent for the mildew disease management. In the bargain, it also seemed to control powdery mildew too. If this extract is applied before and after the flowering season on the vines then even the berries could be saved from the diseases.

\section{Acknowledgement}

The authors are grateful to the authorities of Smt. K.W. College; Sangli for extending the laboratory facilities of the Department of Biotechnology for successful completion of such a time bound project and to one of the authors- Ms. Shweta S. Gurav for permitting to carry out the field trials in her vine yard.

\section{References}

1. (2008) “Grapes - Vitis Spp." University of Georgia.

2. Riaz S, Boursiquot JM, Dangl GS, Lacombe T, Laucou V, et al. (2013) Identification of mildew resistance in wild and cultivated Central Asian grape germplasm. BMC Plant biology 13: 149-152. 
3. Werner S, Steiner U, Becher R, Kortekamp A, Zyprian E, Deising HB (2002) Chitin synthesis during in planta growth and asexual propagation of the cellulosic oomycete and obligate biotrophic grapevine pathogen Plasmopara viticola. FEMS Microbiol Lett 208(2): $169-173$

4. Rouxel M, Mestre P, Baudoin A, Carisse O, Delière L, et al. (2014) Geographic distribution of cryptic species of Plasmopara viticola causing downy mildew on wild and cultivated grape in eastern North America. Phytopathology 104: 692-701.

5. Gadoury DM, Cadle-Davidson L, Wilcox WF, Dry IB, Seem RC, et al. (2012) Grapevine powdery mildew (Erysiphe necator): a fascinating system for the study of the biology, ecology and epidemiology of an obligate biotroph, Mol Plant Pathol 13(1): 1-6.

6. Angelotti F, Hamada E, Magalhães EE, Ghini R, Garrido LR, et al. (2017) Climate change and the occurrence of downy mildew in Brazilian grapevines. Pesquisa Agropecuária Brasileira 52: 426-434.

7. Srinivasan N, Jeyarajan R (1974) Control of downy mildew of grapes assay of fungicides, Hindustan antibiotic bulletin. Hindustan Antibiotics Bulletin 17: 7-11.
8. Julia M (1987) "Sugar Apple Annona squamosa". Fruits of warm climates. Department of Horticulture \& Landscape Architecture, Purdue University p. 69.

9. Ambujavalli BT, Kindo AJ, Veeraraghavan M (2015) Malassezia-Can it be Ignored? Indian J Dermatol 60(4): 332-339.

10. Redfern J, Kinninmonth M, Burdass D, Verran J (2014) Using soxhlet ethanol extraction to produce and test plant material (essential oils) for their antimicrobial properties. J Microbiol Biol Educ 15(1): 45-46.

11. Miller L, Houghton JA (1945) The MicroKjeldahl determination of the nitrogen content of amino acids and proteins. Journal of Biological Chemistry 159: 373-383.

12. Mariotti F, Tome D, Mirand PP (2008) Converting Nitrogen into Protein - Beyond 6.25 and Jones' Factors. Critical reviews in food science and nutrition 48: 177-184.

\section{Your next submission with Juniper Publishers will reach you the below assets}

- Quality Editorial service

- Swift Peer Review

- Reprints availability

- E-prints Service

- Manuscript Podcast for convenient understanding

- Global attainment for your research

- Manuscript accessibility in different formats ( Pdf, E-pub, Full Text, Audio)

- Unceasing customer service

Track the below URL for one-step submission https://juniperpublishers.com/online-submission.php 